University of Nebraska - Lincoln

DigitalCommons@University of Nebraska - Lincoln

Publications from USDA-ARS / UNL Faculty

U.S. Department of Agriculture: Agricultural

Research Service, Lincoln, Nebraska

December 2005

\title{
LOSS OF NITRATE-NITROGEN BY RUNOFF AND LEACHING FOR AGRICULTURAL WATERSHEDS
}

\author{
M. A. Elrashidi \\ USDA-NRCS \\ M. D. Mays \\ USDA-NRCS
}

A. Fares

University of Hawaii, Honolulu, HI

C. A. Seybold

USDA-NRCS

J. L. Harder

USDA-NRCS

See next page for additional authors

Follow this and additional works at: https://digitalcommons.unl.edu/usdaarsfacpub

Part of the Agricultural Science Commons

Elrashidi, M. A.; Mays, M. D.; Fares, A.; Seybold, C. A.; Harder, J. L.; Peaslee, S. D.; and VanNeste, Pam, "LOSS OF NITRATE-NITROGEN BY RUNOFF AND LEACHING FOR AGRICULTURAL WATERSHEDS" (2005). Publications from USDA-ARS / UNL Faculty. 152.

https://digitalcommons.unl.edu/usdaarsfacpub/152

This Article is brought to you for free and open access by the U.S. Department of Agriculture: Agricultural Research Service, Lincoln, Nebraska at DigitalCommons@University of Nebraska - Lincoln. It has been accepted for inclusion in Publications from USDA-ARS / UNL Faculty by an authorized administrator of DigitalCommons@University of Nebraska - Lincoln. 


\section{Authors}

M. A. Elrashidi, M. D. Mays, A. Fares, C. A. Seybold, J. L. Harder, S. D. Peaslee, and Pam VanNeste 


\title{
LOSS OF NITRATE-NITROGEN BY RUNOFF AND LEACHING FOR AGRICULTURAL WATERSHEDS
}

\author{
M. A. Elrashidi', M. D. Mays', A. Fares, C. A. Seybold', J. L. Harder', \\ S. D. Peaslee', and Pam VanNeste ${ }^{1}$
}

The loss of nutrients in runoff and leaching water from agricultural land is a major cause of poor water quality in the United States. Scientists (NRCS) developed a technique to estimate the impact of agricultural watersheds on natural water resources. The objectives were to apply the technique on Wagon Train (WT) watershed in Nebraska to predict: (i) loss of water by surface runoff and subsurface leaching, (ii) loss of nitrate-N from soils by runoff and leaching, and (iii) nitrate-N loading for WT reservoir. The annual loss of water was estimated at 4.32 million $\mathrm{m}^{3}$ for runoff and 0.98 million $\mathrm{m}^{3}$ for leaching. The observed annual inflow for WT reservoir was 4.25 million $\mathrm{m}^{3}$. The predicted annual nitrate- $\mathrm{N}$ loss by runoff was about $7.0 \mathrm{Mg}$ and could be considered the annual loading for the reservoir. The predicted nitrate-N loss by leaching was $7.73 \mathrm{Mg}$, however, the fate was not clear. The estimated average nitrate- $N$ concentration in runoff and leaching water at field sites was 1.63 and $7.88 \mathrm{mg} / \mathrm{L}$, respectively. The observed nitrate- $\mathrm{N}$ concentration in water samples taken from 12 major streams ranged between 0.37 and $1.56 \mathrm{mg} / \mathrm{L}$ with an average of $0.90 \mathrm{mg} / \mathrm{L}$. Nitrogen uptake by algae, weeds, and aquatic plants and emission of gaseous nitrogen oxides from fresh water under reducing conditions might explain the lower nitrate- $N$ concentration. No attempt was made to monitor the nitrate- $\mathrm{N}$ concentration in soil leachate or groundwater. When factors affecting $N$ concentration in streams are considered, the technique could provide a reasonable estimation of $\mathrm{N}$ concentration in stream water. We concluded that the technique could be applied to estimate the loss of nitrate- $\mathrm{N}$ by runoff and leaching from soils and the impact on surface waters. (Soil Science 2005;170:969-984)

Key words: Runoff nitrate-N, leaching water, leaching nitrate-N, runoff water, agricultural watershed.

T HE presence of nitrates and other soluble forms of nitrogen and phosphorus in surface and groundwaters can deteriorate water quality in relation to freshwater eutrophication and potability. Soluble $N$ and $P$ compounds are related to the undesirable growth of algae and aquatic plants which deplete oxygen and kill fish and other aquatic life in surface freshwater bodies (Fruh, 1967). The U.S. Public Health

UUSDA-NRCS, National Soll Survey Center, 100 Centennial Mat, North Lincoln, NE 68508-3866. Dr. Elrashidi is corresponding author. E-mail: moustafs.elrashididusda.gov

sUniversity of Hawditi Honolulu, HI 96899.

Received.March 29, 2005; accepted June 25, 2005.

DOI: $10.1097 / 01.5 s .0000187353 .24364 .08$
Service, and the USEPA has established $10 \mathrm{mg} / \mathrm{L}$ nitrate- $N$ as the maximum contaminant limit (MCL) in drinking water for humans and animals (USEPA, 1992). Levels above $10 \mathrm{mg} / \mathrm{L}$ can lead to methemoglobinemia, or "blue baby" syndrome, which is caused by the reduction of oxygen carrying capacity of blood and can lead to brain damage and death.

The Central Platte Natural Resources District of Nebraska sponsored a study of groundwater quality across the Central Platte valley. The results indicated that approximately $20 \%$ of the valley had groundwater nitrate- $N$ concentration that exceeded $10 \mathrm{mg} / \mathrm{L}$ (Bishop, 1994). In other studies on the Central Platte valley, Gormly and Spalding (1979) and Schepers et al. 
(1991) concluded that commercial fertilizers applied to cropland are the major source of groundwater nitrate- $\mathrm{N}$ in Nebraska.

Managing nonpoint sources of contamination from agricultural land is technically complex. Contamination sources often are located over a large geographic area and are difficult to identify. Identifying hot spots within a watershed enable more efficient use of funds to alleviate potential problems and protect water resources. There are good models that can estimate the impact of nonpoint sources of contamination from agricultural watersheds. However, -these models are too complex and expensive because they require very extensive data input. The NRCS developed an exploratory technique (Elrashidi et al., 2004) to estimate nitrate-N loss by runoff and leaching for agricultural watersheds. The technique is quick and cost-effective because it utilizes existing climatic, hydrologic, and soil survey databases.

The NRCS technique applies the USDA runoff (USDA/SCS, 1991) and a percolation model (Williams and Kissel, 1991) to estimate losses of runoff and leaching water from soils by rainfall. The technique assumes that soluble nutrients such as nitrate- $N$ are lost from a specific depth of surface soil that interacts with runoff and leaching water. A brief description of the technique is reported in the Materials and Methods section. The objectives of this study were to apply this technique on a watershed (Wagon Train) in Southeast Nebraska to estimate: (i) loss of water by runoff and leaching, (ii) loss of nitrate- $N$ from soils by runoff and leaching, and (iii) nitrate-N loading for Wagon Train reservoir.

\section{MATERIALS AND METHODS}

\section{Wagon Train Watershed}

Wagon Train (WT) watershed has a 315-acre (128 hectare) reservoir located on the Hickman Branch of Salt Creek (Platte River Basin) in Lancaster County, Nebraska (Fig. 1). The reservoir was constructed primarily as a flood control structure by the U.S. Army Corps of Engineers in 1962. The total drainage area encompass 9,984 acres (4042 hectare) of agricultural land. Most of the area $(70 \%)$ is cultivated with crops [soybean (glycine willd), corn (zea mays L.), wheat (triticum aestivum $L_{\text {.) }}$, sunflower (helianthus $L$.), and alfalfa (nedicago sativa L.)]. The rest of the watershed is mostly covered with grassland, whereas forest- land, wetland, and urban development account for small areas.

The watershed topography is moderately sloping, and soils are well drained. The land relief consists of uplands, stream terraces and bottom lands. There are 33 miles $(53 \mathrm{~km})$ of streams in the watershed, and 40 ponds ranging in size from 0.3 to 6.5 acres ( 0.12 to 2.6 hectare). Overland flow enters the reservoir through intermittent tributaries. From the dam, the water flows into the Hickman Branch of Salt Creek which flows west and north through Lincoln, and eventually to the Platte River near Ashland, Nebraska.

The watershed has three major soil associations. The Wymore-Pawnee association consists of deep, nearly level to sloping soils, located on ridge tops and side slopès: Wymore (Fine, montmorillonitic, mesic Aquic Argiudolls); Pawnee (Fine, montmorillonitic, mesic Aquic Argiudolls). The Pawnee-Burchard association consists of deep, gently to steeply sloping, loamy and clayey upland soils that developed in glacial till:-Burchard (Fine-loamy, mixed, mesic Typic Argiudolls). The Kennebéc-Nodaway-Zook association contains deep, nearly level or gently sloping silty soils formed in alluvium on floodplains: Kennebec (Fine-silty, mixed, mesic Cumulic Hapludolls); Nodaway (Fine-silty, mixed, nonacid, mesic Mollic Udifluvents); Zook (Fine, montmorillonitic, mesic Cumilic Hapaquolls).

We used soil associations on the general soil map in the Soil Survey Report of Lancaster County, Nebraska (Brown et al., 1980) to determine the major soil series and phases in WT watershed. Nine soil series (Wymore, Pawnee, Nodaway, Sharpsburg, Mayberry, Colo, Judson, Burchard, and Kennebec) account for $96.1 \%$ of the agricultural land. Nearly three-quarters of the watershed consist of Wymore and Pawnee soils.

\section{Soil and Water Sampling}

Soil sampling included each of three widely existent phases of Wymore (Wymore-WtB, $-\mathrm{WtC} 2$, and -WtD3) and two phases of Pawnee (Pawnee-PaC2 and -PaD2), along with the 'other seven soil series. This approach produced a total of 12 soil map units to sample. Soil samples were collected from cropland and grassland within each map unit. Recently, updated soil survey activities have split Sharpsburg into three soil series (Tomek, Yutan, and Aksarben). The new classification, however, should not affect results given in this study. 


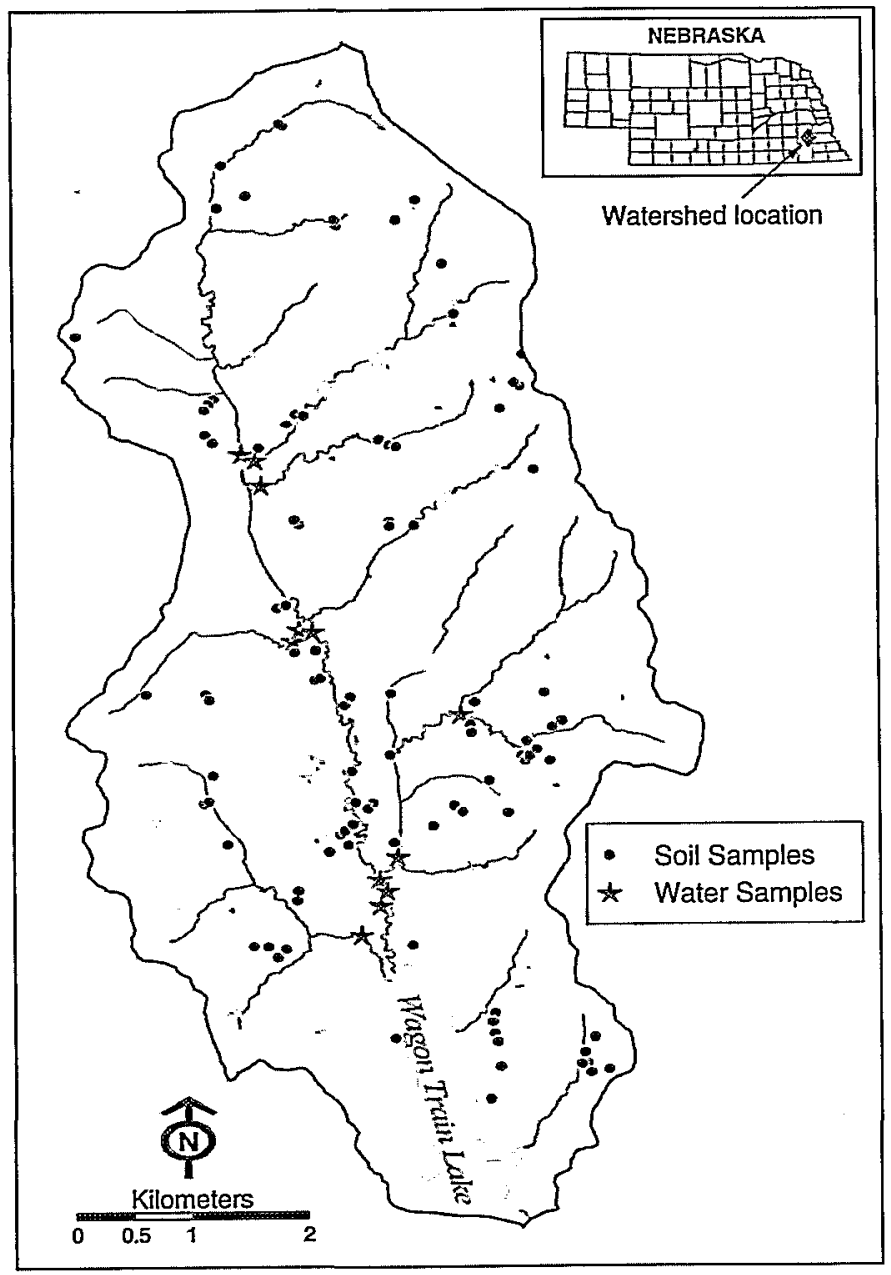

Fis. 1. Soil and water sampling locations in Wagon Train watershed, Lancaster County, Nebraska.

Representative soil samples were taken from each of the 12 soil map units. To distribute sampling locations evenly within the agricultural area, the watershed was divided into six sections. An equal number of samples were taken at random from each section. In total, 72 soil samples from cropland and 24 from grassland were collected (Fig. 1).

At the randomly selected sampling sites, three cores were taken from the top 30-cm soil layer and mixed thoroughly in a stainless steel tray. An approximately $2-\mathrm{kg}$ composite sample was packed in a plastic bag and sealed. Sampling was completed during April of 2003 before fertilizer application for the summer crop.

Many small streams receive surface water runoff from the agricultural land in the watershed. Eventually, streams located northerly of the reservoir join in a single stream that runs southerly about $0.5 \mathrm{~km}$ before entering the reservoir near the north edge. Water samples taken along the main stream were assumed to represent the surface water runoff generated from the entire watershed.

Most of the surface water runoff from the agricultural land in WT watershed and water inflow for WT reservoir are expected during the rainy season in the spring, summer, and early fall (March through October). In the middle of March, water samples were collected at 12 locations for major streams in the watershed (Fig. 1). These samples include three locations along the main stream before entering the reservoir. The analysis for major streams proved that samples taken from the main stream are representative for runoff generated from the entire watershed. 
Accordingly, during the period from April to October, monthly samples were collected only from the three locations along the main stream.

All water samples were taken from streams under base flow conditions to ensure a clear runoff with almost no suspended particulates. Samples were collected (grab) in midstream, by using 1-I polyethylene bottles that have been rinsed twice with stream water before sample. collection. The water samples were taken immediately to the laboratory and refrigerated at $4{ }^{\circ} \mathrm{C}$. The water analysis was completed within a week. The soil and water sampling locations are shown in Fig. 1.

\section{Soil and Water Analysis}

Soil samples were analyzed on air-dried $<2$ $\mathrm{mm}$ soil by methods described in Soil Survey Investigations Report (SSIR) No. 42 (USDA/ NRCS, 1996). Alphanumeric codes in parentheses next to each method represent specific standard operating procedures. Particle-size analysis was performed by sieve and pipette method (3A1). Cation exchange capacity (CEC) was conducted by $\mathrm{NH}_{4} \mathrm{OAc}$ buffered at $\mathrm{pH} 7.0$ (5A8b). Total carbon $(C)$ content was determined by dry combustion (6A2f) (Vario EL III, Elementar Americanas, Inc., Mt. Laurel, NJ), and $\mathrm{CaCO}_{3}$ equivalent was estimated by electronic manometer method (6E1g). Organic $\mathrm{C}$ in soil was estimated from both the total-, and $\mathrm{CaCO}_{3}-$ C. Soil $\mathrm{pH}$ was measured in a $1: 1$ soil/water suspension (8C1f). Liquid limit was determined by the American Society for Testing and Materials method D 4318 (ASTM, 1993). Soluble nitrate- $\mathrm{N}$ was extracted with $1.0 \mathrm{M} \mathrm{KCl}$ solution and measured by the flow injection, automated ion analyzer LACHAT Instruments (6M2a). Classification, and selected properties for soils under crop and grass in WT watershed are given in Table 1.

Stream-water samples were filtered by using a glass syringe equipped with Whatman $25-\mathrm{mm}$ $\mathrm{GD} / \mathrm{X}$ disposable nylon filter media $(0.45 \mu \mathrm{m}$ pore size). Nitrate- $N$ concentration in the filtrate was determined by the High Pressure Ion Chromatograph (6M1c) (HPIC, Dionex Corp.) and $\mathrm{pH}$ by the combination electrode and Digital $\mathrm{pH}$ /ion meter, Model 950, Fisher Scientific (8C1a) as described inUSDA/NRCS (1996).

\section{Estimation of Runoff Water}

Rainfall is the primary source of water that runs off the surface of small agricultural watersheds. The main factors affecting the volume of rainfall that runs off are the kind of soil and the type of vegetation in the watershed (USDA/ SCS, 1991). The runoff equation can be written as follows:

$$
Q=(R-0.2 S)^{2} \div(R+0.8 S)
$$

where $Q=$ runoff (inches), $R=$ rainfall (inches), and $S=$ potential maximum retention (inches) after runoff begins.

The potential maximum retention ( $\mathrm{S}$ ) can range from zero on a smooth and impervious surface to infinity in deep gravel. The $S$ value is converted to a runoff curve number (CN), which is dependent on both the hydrologic soil group and type of land cover by the following equation:

$$
\mathrm{CN}=1000 \div(10+\mathrm{S})
$$

According to Eq. (2), the $\mathrm{CN}$ is 100 when $\mathrm{S}$ is zero and approaches zero as $S$ approaches infinity. Runoff curve numbers (CNs) can be any value from zero to 100 , but for practical applications are limited to a range of 40 to 98 . Substituting Eq. (2) into Eq. (1) gives

$$
\begin{aligned}
\mathrm{Q} & =\{\mathrm{R}-[2(100-\mathrm{CN}) / \mathrm{CN}]\}^{2} \\
& \div\{\mathrm{R}+[8(100-\mathrm{CN}) / \mathrm{CN}]\}
\end{aligned}
$$

In this study, hydrologic groups of the 12 soil map units investigated were used to determine CNs for fallow, crop (cropland) and grass (grassland). Further, the annual rainfall at various soil locations were taken from the USDA/ NRCS National Water and Climate Center (NWCC, 2003).

USDA/SCS (1991) developed the runoff equation [Eq. (3)] to estimate runoff from small agricultural watersheds by 24-hour rainfall event. It was assumed the 24-hour storm was an effective rainfall $(R)$ that could generate runoff. In this study, however, we applied the runoff equation to estimate runoff by an annual rainfall. It was assumed $20 \%$ of an annual rainfall in Lancaster County $(730 \mathrm{~mm})$ would generate runoff. The effective rain $(R)=$ (annual rainfall $\div 5$ ). We used runoff information reported in the average annual runoff of the United States, 1951 to 1980 (Gilbert et al., 1987) to make that assumption. This approach has an insignificant effect on runoff value derived from the runoff equation [Eq. (3)] because of the similarity of the effective rain value ( $R$ ) used in both cases. However, it enables us to predict runoff water for an annual rainfall rather than a storm event, which is desirable to the scientific and agricultural communities. 
TABLE 1

Classification and some properties for 12 major soils under crop and grass cover in Wagon Train watershed,

Lancaster County, Nebraska

\begin{tabular}{|c|c|c|c|c|c|c|c|c|}
\hline Soil (map unit) & Classification & Land use & $\begin{array}{l}\text { Clay } \\
(\%)\end{array}$ & $\begin{array}{l}\mathrm{OM} \\
(\%)\end{array}$ & $\begin{array}{c}\mathrm{CEC} \\
(\mathrm{cmol} / \\
\mathrm{kg})\end{array}$ & $\begin{array}{l}\mathrm{pH}- \\
\text { water }\end{array}$ & $\begin{array}{c}\text { Liquid } \\
\text { limit (mL/ } \\
\mathrm{kg} \text { soil) } \\
\end{array}$ & $\begin{array}{l}\text { Hydrologic } \\
\text { group }\end{array}$ \\
\hline \multirow[t]{2}{*}{ Wymore (WtB) } & \multirow{2}{*}{$\begin{array}{l}\text { Fine, montmorillonitic, } \\
\text { mesic Aquic Argiudolls }\end{array}$} & Cropland & 37.3 & 2.14 & 25.90 & 5.56 & 465 & $\mathrm{D}$ \\
\hline & & Grassland & 32.9 & $2 .+4$ & 25.70 & 5.90 & 465 & $\mathrm{D}$ \\
\hline \multirow[t]{2}{*}{ Wymore (WtC2) } & \multirow{2}{*}{$\begin{array}{l}\text { Fine, montmorillonitic, } \\
\text { mesic Aquic Argiudolls }\end{array}$} & Cropland & 37.9 & 2.23 & 26.50 & 5.70 & 465 & $\mathrm{D}$ \\
\hline & & Grassland & 35.6 & 3.46 & 28.20 & 5.80 & 465 & $\mathrm{D}$ \\
\hline \multirow[t]{2}{*}{ Wymore (WtD3) } & \multirow{2}{*}{$\begin{array}{l}\text { Fine, montmorillonitic, } \\
\text { mesic Aquic Argiudolls }\end{array}$} & Cropland & 41.2 & 2.16 & 29.30 & 5.85 & 465 & $\mathrm{D}$ \\
\hline & & Grassland & $3+.2$ & 2.78 & 28.90 & 6.40 & 465 & $\mathrm{D}$ \\
\hline \multirow[t]{2}{*}{ Pawnee $(\mathrm{PaC} 2)$} & \multirow{2}{*}{$\begin{array}{l}\text { Fine, montmorillonitic, } \\
\text { mesic Aquic Argiudolls }\end{array}$} & Cropland & 35.2 & 1.94 & 24.90 & 5.64 & 475 & $\mathrm{D}$ \\
\hline & & Grassland & 29.3 & 2.38 & 21.70 & 5.55 & 475 & $\mathrm{D}$ \\
\hline \multirow[t]{2}{*}{ Pawnee ( $\mathrm{PaD} 2)$} & \multirow{2}{*}{$\begin{array}{l}\text { Fine, montmorillonitic, } \\
\text { mesic Aquic Argiudolls }\end{array}$} & Cropland & 34.9 & 1.85 & 24.50 & 5.79 & 475 & $\mathrm{D}$ \\
\hline & & Grassland & 34.7 & 2.39 & 25.50 & 6.10 & 475 & D \\
\hline \multirow{2}{*}{$\begin{array}{l}\text { Nodaway (No, } \\
\text { Ns) }\end{array}$} & \multirow{2}{*}{$\begin{array}{l}\text { Fine-silty, mixed, } \\
\text { nonacid, mesic Mollic } \\
\text { Udifluvents }\end{array}$} & Cropland & 29.4 & 2.08 & 24.40 & 6.58 & 300 & $\mathrm{~B}$ \\
\hline & & Grassland & 30.1 & 2.97 & 26.40 & 6.25 & 300 & $\mathrm{~B}$ \\
\hline \multirow{2}{*}{$\begin{array}{l}\text { Sharpsburg } \\
\text { (ShC, ShD, } \\
\text { ShD2) }\end{array}$} & \multirow{2}{*}{$\begin{array}{l}\text { Fine, montmorillonitic, } \\
\text { mesic Typic Argiudolls }\end{array}$} & Cropland & 39.7 & 1.94 & 27.60 & 5.70 & 450 & $\mathrm{~B}$ \\
\hline & & Grassland & 37.4 & 2.05 & 27.00 & 6.15 & 450 & $\mathrm{~B}$ \\
\hline \multirow{2}{*}{$\begin{array}{l}\text { Mayberry } \\
\text { (MeC2, MeD2, } \\
\text { MhC3) }\end{array}$} & \multirow{2}{*}{$\begin{array}{l}\text { Fine, montmorillonitic, } \\
\text { mesic Aquic Argiudolls }\end{array}$} & Cropland & 31.8 & 1.96 & 22.80 & 5.99 & 400 & $\mathrm{D}$ \\
\hline & & Grassland & 26.0 & 2.08 & 20.40 & 6.50 & 400 & $\mathrm{D}$ \\
\hline \multirow[t]{2}{*}{ Colo $\left(\mathrm{Co}, \mathrm{Cp}_{\mathrm{p}}\right)$} & Fine-silty, mixed, mesic & Cropland & 32.1 & 2.13 & 25.00 & 6.30 & 500 & C \\
\hline & Cumulic Hapludolls & Grassland & 29.0 & 2.95 & 26.10 & 6.10 & 500 & C \\
\hline \multirow[t]{2}{*}{ Judson (JuC) } & Fine-silty, mixed, mesic & Cropland & 32.0 & 2.26 & 24.80 & 6.05 & 378 & B \\
\hline & Cumulic Hapludolls & Grassland & 30.5 & 3.06 & 24.00 & 6.00 & 378 & $\mathrm{~B}$ \\
\hline \multirow{4}{*}{$\begin{array}{l}\text { Burchard }(\mathrm{BpF}, \\
\mathrm{BrD}, \mathrm{BrE}) \\
\text { Kennebec }(\mathrm{Ke})\end{array}$} & Fine-loamy, mixed, & Cropland & 29.8 & 1.89 & 21.70 & 5.96 & 425 & $\mathrm{~B}$ \\
\hline & mesic Typic Argiudolls & Grassland & 30.1 & 2.99 & 23.10 & 7.00 & 425 & B \\
\hline & Fine-silty, mixed, mesic & Cropland & 27.6 & 1.94 & 20.70 & 5.95 & 350 & $\mathrm{~B}$ \\
\hline & Cumulic Hapludolls & Grassland & 24.7 & 2.09 & 19.50 & 6.10 & 350 & $\mathrm{~B}$ \\
\hline
\end{tabular}

For each soil, both the runoff curve number $(C N)$ and effective rainfall $(R)$ values were applied in the runoff equation [Eq. (3)] to calculate the runoff $(Q)$ for fallow, crop, and grass. Noteworthy, Eq. (3) calculated runoff values in inches. In this study, the $Q$ values were converted to millimeters.

\section{Estimation of Leaching Water}

The amount of water that leaches from soil was determined by a model developed by Williams and Kissel (1991). The authors used an equation of the form used to estimate surface runoff water [Eq. (3)] to develop their equation that predicts the percolation index $(\mathrm{PI})$.

$$
\mathrm{PI}=(\mathrm{P}-0.4 r)^{2} /(\mathrm{P}+0.6 r)
$$

Where PI is an estimate of average annual percolation in inches, $P$ is the average annual rainfall in inches, and $\boldsymbol{r}$ is a retention parameter. The retention parameter $(r)$ is related to a Per- colation Curve Number (PCN) by using the equation

$$
r=(1000 / \mathrm{PCN})-10
$$

The values of PCN are 28,21, 17, and 15 for hydrologic soil groups A, B, C, and D, respectively (Williams and Kissel, 1991).

Another factor of considerable importance in estimating percolation is the seasonal rainfall distribution. Rainfall that occurs in the absence of crops is much more likely to percolate than growing season rainfall (i.e., spring and summer) because evapotranspiration is low during the fall and winter.Williams and Kissel (1991) introduced the Seasonal Index (SI) to estimate the seasonal precipitation effects on percolation.

$$
\mathrm{SI}=(2 \mathrm{PW} / \mathrm{P})^{1 / 3}
$$

where $P W$ is the effective precipitation (rainfall occurs in the absence of crops), and $P$ is the 
annual precipitation. The effective precipitation (PW) for cropland in WT watershed was computed by summing the values for October through May. Assuming evapotranspiration was very low during the winter, December, January, and February were used to calculate PW for grassland. For fallow, however, PW $=\mathrm{P}$ because of the absence of any land cover throughout the entire year.

The Leaching Index (LI) was estimated by combining Eqs. (4) and (6) as follows:

$$
\mathrm{LI}=(\mathrm{PI})(\mathrm{SI})
$$

For the 12 soil map units investigated, the amount of leaching water was calculated by using the LI for fallow (bare soil), cropland, and grassland.

\section{Observed Inflow for WT Reservoir}

In 1962, the dam on a tributary of Salt Creek and construction of the Wagon Train reservoir were completed. However, United States Geological Survey (USGS, 2001) has monitored the water flow in Salt Creek and streams in the Platte River basin long before the construction of WT reservoir. The Salt Creek gage at Roca (USGS gage No. 06803000 , hydrologic unit 10200203, Lancaster County, Nebraska) with a period of record from 1951 to 2000 provided average monthly water flow rate values for a drainage area of 106,880 acres (43,286 hectare) encompassing WT watershed (USGS, 2001). Recently, the Lower Platte South Natural Resources District (LPSNRD, 2004) used the ratio of the watershed to the Salt Creek drainage area (9.34\%) to calculate the average monthly water flow rate values for WT watershed. In this study, we used these average monthly water flow rate values to calculate the observed inflow for WT reservoir.

\section{Estimating Nitrate-N Loss by Runoff and Leaching}

Nutrients such as $N, K, P$, and other agricultural chemicals are released from a thin layer of surface soil that interacts with rainfall and runoff. In chemical transport models, the thickness of the interaction zone is determined by model calibration with experimental data, with depths ranging between 2.0 and $6.0 \mathrm{~mm}$ (Donigian et al., 1977). Frere et al. (1980), however, suggested an interaction zone of $10 \mathrm{~mm}$, assuming that only a fraction of the chemical present in this depth interacts with rain- fall water. In other studies in this laboratory, Elrashidi et al. $(2003,2004,2005)$ used a fixed soil thickness of $10 \mathrm{~mm}$ to estimate $P$ and nitrate-N loss by runoff for agricultural land. In this study, the nitrate- $\mathrm{N}$ measured in soil is the net product of all chemical and biological reactions affecting nitrate- $\mathrm{N}$ in soil (i.e., mineralization, nitrification, and immobilization).

In this study, we used an interaction zone of $10 \mathrm{~mm}$ to calculate the amount of nitrate- $\mathrm{N}$ released from surface soils by runoff. Also, it was assumed that during the runoff occurrence, water content in the surface 10-mm soil depth is at the liquid limit, the moisture content at which the soil passes from a plastic to a liquid state. Thus, during the runoff occurrence, the total amount of water (where nitrate- $\mathrm{N}$ in the $10-\mathrm{mm}$ soil depth is dissolved) is the sum of water within the soil body (liquid limit), and that on the surface of soil (runoff water). The volume of water in the $10-\mathrm{mm}$ soil depth is usually very small when compared with runoff water. Only nitrate- $\mathrm{N}$ in runoff water is removed and lost during the runoff occurrence. For the 12 map units investigated, amounts of nitrate$\mathrm{N}$ loss by runoff were calculated as $\mathrm{kg} / \mathrm{ha} / \mathrm{yr}$.

Hubbard et al. (1991) and Lowrance (1992) studied nitrate- $\mathrm{N}$ losses from a small watershed $(0.34 \mathrm{ha})$ in south Georgia. They found that most of the nitrate- $\mathrm{N}$ losses were leached from the top $30-\mathrm{cm}$ soil layer when $620 \mathrm{~mm}$ of natural rainfall followed fertilizer application. Further, in a field experiment in Wisconsin, Olsen et al. (1970) investigated the effect of spring and summer rainfall (average $55 \mathrm{~cm}$ ) on downward movement of $\mathrm{N}$ for soils under corn, that received $336 \mathrm{~kg} \mathrm{NH}_{4} \mathrm{NO}_{3} / \mathrm{ha}$. At the end of summer, they found that $<10 \%$ of applied-N remained within the top $30 \mathrm{~cm}$ of the soil.

In this study, to calculate nitrate-N loss by leaching, we assumed (i) rain water leaching through the surface $30 \mathrm{~cm}$ of the soil profile initiates downward movement of nitrate- $\mathrm{N}$, and (ii) a leaching index (LI) equivalent to the annual rainfall in Lancaster County, Nebraska $(730 \mathrm{~mm})$ can leach all nitrate-N present in the top 30-cm soil depth.

The downward movement of water (carrying dissolved nitrate-N) from the top soil ( $30-\mathrm{cm}$ soil depth) is the major mechanism by which nitrate- $\mathrm{N}$ is lost from the root zone. A leaching index (LI) equivalent to the annual rainfall in Lancaster County $(730 \mathrm{~mm})$ caniremove nitrate$\mathrm{N}$ beneath the root zone $(30-\mathrm{cm}$ soil depth). The loss of nitrate- $\mathrm{N}$ is dependent on the 
predicted depth of water leaching through the top $30-\mathrm{cm}$ of soil. The ratio of predicted leaching water depth to the annual rainfall $(730 \mathrm{~mm})$ is used to estimate the downward movement (loss) of nitrate- $\mathrm{N}$ from the top $30-\mathrm{cm}$ of soil. For example, a predicted leaching water depth of $73 \mathrm{~mm}$ for a soil will result in downward movement of $10 \%(73 / 730)$ of nitrate- $\mathrm{N}$ present in the top $30-\mathrm{cm}$ of soil. For each soil the authors used the predicted leaching water $(\mathrm{mm} / \mathrm{yr})$ and concentration of nitrate- $\mathrm{N}$ ( $\mathrm{mg} / \mathrm{kg}$ soil) in the surface $30-\mathrm{cm}$ of soil to calculate nitrate- $\mathrm{N}$ loss by leaching for soil under fallow, crop, and grass.

\section{GIS Digital Mapping}

Digital maps for Water and P losses from agricultural land in WT watershed, Lancaster County, Nebraska were generated by Geographical Information Systems (GIS) software. The GIS software used was ArcView 8.3 (ESRI, 2003). The input required to generate the map included spatial data layers (soil series and land cover) and the tabular data from both the runoff and leaching as well as nitrate- $\mathrm{N}$ (water and nitrate- $\mathrm{N}$ loss from soils and concentration in runoff and leaching water).

The principal spatial data layer used was the Soil Survey Geographic (SSURGO) (USDA/ NRCS, 1999). Both the National Land Cover (NLCD, 1992), and National Agricultural Sta- tistics Service (NASS, 2003) spatial layers were used to identify areas of cropland and grassland within the county. Other types of land cover such as urban, forest, water or marsh were not mapped for the watershed. The proposed technique calculated water and nitrate- $N$ losses and $N$ concentration in runoff and leaching water for soils under different types of land cover (fallow, crop and grass). Thus, GIS mapping of agricultural land in the watershed included data layers for soils and land cover as well as water or soil nitrate- $N$.

\section{RESULTS AND DISCUSSION}

\section{Runoff and Reservoir Inflow}

The predicted annual loss of water by runoff $\left(\mathrm{m}^{3} / \mathrm{ha} / \mathrm{yr}\right)$ for 12 soil map units under different land covers in WT watershed is given in Table 2. Actually, fallow (bare soils) did not constitute a large area in the watershed. But, it was included to provide a worst-case scenario if heavy storms and runoff events have occurred during crop field preparations or early growth's stage for the summer crop (April to June). Accordingly, the area of cropped soils ( $70 \%$ of the watershed) was also used to predict the runoff water for fallow. Grass covered the remainder of the watershed.

Generally, the annual loss of water from soil by runoff was slightly higher for fallow than

TABLE 2

Predicted loss of surface water by runoff and leaching $\left(\mathrm{m}^{3} / \mathrm{ha} / \mathrm{yr}\right)$ for 12 major soils under different land covers in Wagon Train watershed, Lancaster County, Nebraska

\begin{tabular}{|c|c|c|c|c|c|c|c|}
\hline \multirow{3}{*}{ Soil (map unit) } & \multirow{3}{*}{ Area* (ha) } & \multicolumn{3}{|c|}{ Runoff water $^{\dagger}$} & \multicolumn{3}{|c|}{ Leaching water ${ }^{\ddagger}$} \\
\hline & & Fallow & Cropland & Grassland & Fallow & Cropland & Grassland \\
\hline & & \multicolumn{3}{|c|}{ - $\left(\mathrm{m}^{3} / \mathrm{ha} / \mathrm{yr}\right) \ldots$} & \multicolumn{3}{|c|}{$\ldots-\left(m^{3} / h a / y r\right) \cdots$} \\
\hline Wymore (WtB) & 558 & 1280 & 1167 & 1000 & 188 & 150 & 80 \\
\hline Wymore (WtC2) & 1815 & 1280 & 1167 & 1000 & 188 & 150 & 80 \\
\hline Wymore (WtD3) & 177 & 1280 & 1167 & 1000 & 188 & 150 & 80 \\
\hline Pawnee $(\mathrm{PaC} 2)$ & $3+3$ & 1280 & 1167 & 1000 & 188 & 150 & 80 \\
\hline Pawnee (PaD2) & 77 & 1280 & 1167 & 1000 & 188 & 150 & 80 \\
\hline Nodaway (No, Ns) & 203 & 1057 & 901 & 640 & 1168 & 936 & 498 \\
\hline Sharpsburg (ShC, ShD, ShD2) & 177 & 1057 & 901 & 640 & 1168 & 936 & 498 \\
\hline Mayberкy (MeC2, MeD2, MhC3) & 157 & 1280 & 1167 & 1000 & 188 & 150 & 80 \\
\hline Colo $(\mathrm{Co}, \mathrm{Cp})$ & 152 & 1195 & 1084 & 880 & 467 & 374 & 199 \\
\hline Judson (JuC) & 101 & 1057 & 901 & 640 & 1168 & 936 & 498 \\
\hline Burchard (BpF, BrD, BrE) & 81 & 1057 & 901 & 640 & 1168 & 936 & 498 \\
\hline Kennebec (Ke) & 45 & 1057 & 901 & 640 & 1168 & 936 & 498 \\
\hline Weighted average total & 3885 & 1242 & 1122 & 939 & 351 & 282 & 150 \\
\hline
\end{tabular}

*Fallow or cropland accounted for $70 \%$ of soil area in the watershed; grassland accounted for $30 \%$ of area.

${ }^{\dagger}$ USDA/SCS (1991).

${ }^{\ddagger}$ William and Kissel (1991). 
cropland, whereas grassland produced relatively lower values. The predicted average (areaweighted) of runoff water was 1242 and $1122 \mathrm{~m}^{3} /$ $\mathrm{ha} / \mathrm{yr}$ for fallow and cropland, respectively. The average for grassland was $939 \mathrm{~m}^{3} / \mathrm{ha} / \mathrm{yr}$. These results accounted for $17.0,15.4$, and $12.9 \%$ of the annual rainfall for fallow, cropland, and grassland, respectively. Similar values were reported for 13 United States soils of humid regions (rainfall $>800 \mathrm{~mm} / \mathrm{yr}$ ) where the average was $16 \%$ for fallow, $15 \%$ for cropland, and $12 \%$ for grassland (Elrashidi et al., 2003).

However; these values were relatively higher than those reported for Lancaster County, Nebraska where the watershed is located (Elrashidi et al., 2004). This could be attributed to the slow water infiltration rate (hydrologic group $D$ ) for the dominant soils. (Wymore, Pownee, and Mayberry) in the watershed. These three soils occupy approximately $80 \%$ of the agricultural land in the watershed.

The results indicated that $\mathrm{W}_{y m o r e-} \mathrm{W}_{\mathrm{tC}} 2$ soil map unit, irrespective of the land cover, produced the highest volume of runoff water mainly because of its abundance in the watershed. On the other hand, Kennebec soil which had very limited area generated the least volume of runoff water. The total annual loss of runoff water from the 12 major soil map units was 4.15 million $\mathrm{m}^{3}$. Under the worst-case scenario (using fallow for all cropland), this value should increase (8\%) to 4.47 million $\mathrm{m}^{3}$. The area of the 12 major soil map units (3885 ha) incorporated about $96 \%$ of the entire watershed. When the entire watershed area (4042 ha) was considered, the total annual runoff accounted for 4.31 million $\mathrm{m}^{3}$ of water.

Figure 2 shows the observed average monthly inflow $\left(\mathrm{m}^{3}\right)$ for WT reservoir for a 50-year period between 1951 and 2000 (USGS, 2001 ), and the predicted surface water runoff $\left(\mathrm{m}^{3}\right)$ for WT watershed. The historic record of monthly rainfall for Lancaster County (NWCC, 2003) was used to predict the runoff water. The runoff model, used in the present study (USDA/ SCS, 1991) appeared to underestimate the observed water flow to the reservoir for February and March while overestimating the inflow for August and September.

According to the historic record of Lancaster County (NWCC, 2003), a total of 23.9 inches $(607 \mathrm{~mm})$ of snow falls during the winter. Usually, a large portion of this snow remains on the ground because of the cold weather. The moderate temperature in early spring could melt much of the snow which increases the water inflow for the reservoir. This snow melt might explain the underestimation of the inflow for February and March.

During the hot summer period, crops such as com and. soybean are in a full growth stage and have a high demand for water. Further, the high temperature and low relative humidity could dry the surface soil and increase evapotranspiration by plants. These combined factors could reduce the runoff and reservoir inflow which may explain the overestimation for August and September. The underestimation in early spring appeared to offset the summer's overestimation and kept the predicted annual runoff water $\left(4.31\right.$ million $\left.\mathrm{m}^{3}\right)$ in good agreement with the observed annual intlow $\left(4.25\right.$ million $\left.\mathrm{m}^{3}\right)$.

\section{Leachitng Water}

The poor hydraulic conductivity of the three dominant soils in the watershed (Wymore, Pawnee, and Mayberry), contributed to a slow water infiltration rate through the vadose zone. Accordingly, the amount of water loss by leaching was generally much lower than by runoff (Table 2). For the dominant soils (map units), the annual water loss by leaching was 188,150 , and $80 \mathrm{~m}^{3} / \mathrm{ha} / \mathrm{yr}$ for fallow, cropland, and grassland, respectively. For other soils (Nodaway, Sharpsburg, Judson, Burchard, and Kennebec) with adequate hydraulic conductivity, the water loss by leaching wạs somewhat similar to runoff. The annual water loss by leaching was 1168,936 , and $498 \mathrm{~m}^{3} / \mathrm{ha} / \mathrm{yr}$ for fallow, cropland, and grassland. ,

When all 12 major soils in the watershed were considered, the predicted average of leaching water was $351 \mathrm{~m}^{3} / \mathrm{ha} / \mathrm{yr}$ for fallow, $282 \mathrm{~m}^{3} / \mathrm{ha} / \mathrm{yr}$ for cropland, and $1.50 \mathrm{~m}^{3} / \mathrm{ha} / \mathrm{yr}$ for grassland. These results accounted for $4.8 \%$ of the annual rainfall for fallow, $3.9 \%$ for cropland, and $2.1 \%$ for grassland. The values were lower than those reported for Lancaster County, Nebraska (Elrashidi et al., 2004), where the average was $10.1,8.0$, and $4.3 \%$ for fallow, cropland, and grassland, respectively. As mentioned above, the poor hydrology and slow water infiltration rate through the vadose zone for the dominant soils, which accounted for $80 \%$ of the agricultural land in the watershed, might explain these relatively low values.

The predicted annual volume of leaching water from all agricultural land in the watershed area (4042 ha) was 0.98 million $\mathrm{m}^{3}$, which accounted for $3.3 \%$ of the annual rainfall. The 


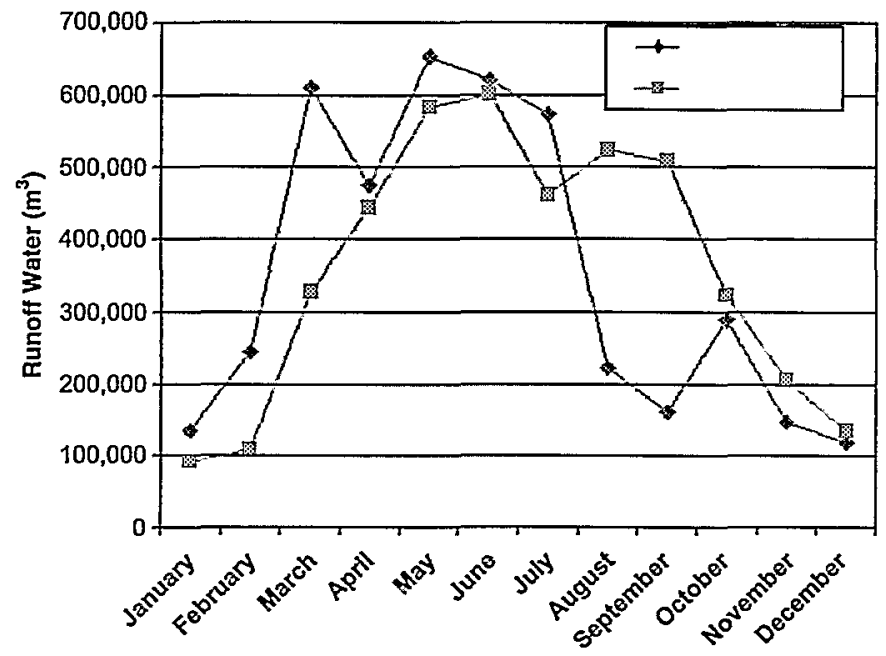

Fig. 2. Predicted average monthly runoff water from Wagon Train (WT) watershed and observed water inflow for WT reservoir.

fate of this water is unclear because we have no information on the direction or velocity of the subsurface water flow. However, the fact that the observed inflow for WT reservoir was derived mainly from the runoff (USGS, 2001), suggested that the leaching water had a minor effect on the reservoir. Further, the lack of oxygen and low redox potential in subsurface soil environments can convert nitrate to less oxidized and immobile $\mathrm{N}$ forms (i.e., ammonium and organic-N). This reducing reaction can limit the effect of leaching $N$ on the reservoir. Accordingly, in this study, we assumed that only nitrate- $\mathrm{N}$ loss from soils to runoff water has contributed to $\mathrm{N}$ loading into the reservoir.

\section{Nitrate-N Loss From Soils}

The loss of nitrate- $\mathrm{N}$ by runoff and leaching water for soils under fallow, crop, and grass (kg/ ha/yr) are given in Table 3. For both fallow and cropped soils, the average loss by runoff was similar at $1.9 \mathrm{~kg} / \mathrm{ha} / \mathrm{yr}$, and it was greater than that in the grassland $(1.27 \mathrm{~kg} / \mathrm{ha} / \mathrm{yr})$. For 110 counties in the High Plains region in the United States, Wu et al. (1997) used five categories to evaluate $N$ loss by runoff: low $(<1.68$

TABLE 3

Predicted amount of nitrate- $\mathrm{N}$ loss by runoff and leaching $(\mathrm{kg} / \mathrm{ha} / \mathrm{yr})$ for 12 major soils under different land covers in Wagon Train watershed, Lancaster County, Nebraska

\begin{tabular}{|c|c|c|c|c|c|c|}
\hline \multirow{3}{*}{ Soil (map unit) } & \multicolumn{3}{|c|}{ Nitrate- $\mathrm{N}$ loss by runoff } & \multicolumn{3}{|c|}{ Nitrate- $\mathrm{N}$ loss by leaching } \\
\hline & Fallow & Cropland & Grassland & Fallow & Cropland & Grassland \\
\hline & \multicolumn{3}{|c|}{ - } & \multicolumn{3}{|c|}{ - $(\mathrm{kg} / \mathrm{ha} / \mathrm{yr})-\ldots$} \\
\hline Wymore (WtB) & 2.64 & 2.63 & 1.31 & 2.13 & 1.71 & 0.46 \\
\hline Wymore (WtC2) & 1.69 & 1.68 & 1.35 & 1.36 & 1.09 & 0.47 \\
\hline Wymore (WtD3) & 1.64 & 1.63 & 0.81 & 1.33 & 1.06 & 0.28 \\
\hline Pawnee $(\mathrm{PaC} 2)$ & 1.99 & 1.98 & 0.99 & 1.61 & 1.29 & 0.35 \\
\hline Pawnee $(\mathrm{PaD} 2)$ & 1.81 & 1.81 & 0.09 & 1.47 & 1.17 & 0.03 \\
\hline Nodaway (No, Ns) & 1.89 & 1.87 & 1.61 & 9.39 & 7.52 & 3.51 \\
\hline Sharpsburg (ShC, ShD, ShD2) & 1.93 & 1.91 & 0.32 & 9.79 & 7.84 & 0.72 \\
\hline Mayberry (MeC2, MeD2, MhC3) & 1.82 & 1.82 & 1.25 & 1.46 & 1.17 & 0.43 \\
\hline Colo (Co, Cp) & 2.17 & 2.16 & 2.91 & 4.39 & 3.52 & 2.56 \\
\hline Judson (JuC) & 2.08 & 2.06 & 1.81 & 10.44 & 8.36 & 3.99 \\
\hline Burchard (BpF, BrD, BrE) & 1.66 & 1.65 & 0.80 & 8.40 & 6.73 & 1.77 \\
\hline Kennebec (Ke) & 1.73 & 1.72 & 0.12 & 8.66 & 6.94 & 0.27 \\
\hline Weighted average total & 1.91 & 1.90 & 1.27 & 2.89 & 2.31 & 0.81 \\
\hline
\end{tabular}

Fallow or cropland accounted for $70 \%$ of soil area in the watershed; grassland accounted for $30 \%$ of area. 
$\mathrm{kg} / \mathrm{ha}$ ), medium-low (1.68 to $3.36 \mathrm{~kg} / \mathrm{ha}$ ), medium ( 3.36 to $5.04 \mathrm{~kg} / \mathrm{ha} / \mathrm{yr})$, medium high (5.04 to $6.72 \mathrm{~kg} / \mathrm{ha})$, and high $(>6.72 \mathrm{~kg} / \mathrm{ha})$. The ranges were determined so that the 110 county-level averages of $\mathrm{N}$ in runoff $(4.71 \mathrm{~kg} / \mathrm{ha})$ falls in the medium range. Therefore, these categories may only be used to compare $\mathrm{N}$ loss across the High Plains region. Accordingly, most soils under fallow and crop cover in the watershed were at medium-low, whereas most grassland soils were categorized at low.

On the other hand, the loss of nitrate- $\mathrm{N}$ by leaching, irrespective of land cover, was greater in soils with a fast water infiltration rate (hydrologic group B) than in those with a slow water infiltration (hydrologic group D). For the former, the annual loss ranged from ' 4.39 to $10.4 \mathrm{~kg} / \mathrm{ha} / \mathrm{yr}$ for fallow, 3.52 to $8.36 \mathrm{~kg} / \mathrm{ha} / \mathrm{yr}$ for cropland, and 0.27 to $3.99 \mathrm{~kg} / \mathrm{ha} / \mathrm{yr}$ for grassland. For the latter, the ranges were 1.33 to $2.13,1.06$ to 1.71 , and 0.03 to $0.47 \mathrm{~kg} / \mathrm{ha} / \mathrm{yr}$ for fallow, cropland, and grassland, respectively. Further, the average for the entire watershed was relatively low at $2.89,2.31$, and $0.81 \mathrm{~kg} / \mathrm{ha} /$ yr for fallow, cropland, and grassland, respectively because of the dominance of soils with poor hydrology and slow water infiltration.

Wu et al. (1997) used the following categories to evaluate $N$ loss by leaching for 110 counties in the High Plains region: low $(<1.12 \mathrm{~kg} / \mathrm{ha})$, medium-low (1.12 to $2.24 \mathrm{~kg} / \mathrm{ha}$ ), medium (2.24 to $3.36 \mathrm{~kg} / \mathrm{ha}$ ), medium-high (3.36 to $4.48 \mathrm{~kg} / \mathrm{ha}$ ), and high $(>4.48 \mathrm{~kg} / \mathrm{ha})$. Comparing losses by leaching in the watershed with those across the High Plains, most soils with fast water infiltration rate, irrespective of land cover, were classified at high or medium-high. Meanwhile, soils of slow infiltration were mostly at the low or medium-low category.

Several studies in the north central region of the United States (i.e.,Olsen et al., 197.0, in Wisconsin;Gast et al., 1978, in Minnesota) reported greater amounts of nitrate- $\mathrm{N}$ leaching losses than those found in this study. Timmons and Dylla (1981) reported average annual nitrate- $N$ leaching losses to range from 29 to $112 \mathrm{~kg} / \mathrm{ha}$ for a corn field during a 5-year period in central Minnesota. In southwest Michigan, Rasse et al. (1999) found application of 101 and $202 \mathrm{~kg} \mathrm{~N} / \mathrm{ha}$ to a maize field during a 5-year period generated an average nitrate- $\mathrm{N}$ leaching loss of 26 and $60 \mathrm{~kg} / \mathrm{ha} / \mathrm{yr}$, respectively, during the last 2 years of treatment. These large leaching losses in the north central region might be a result of higher annual precipitation, coarser soil texture, and faster rate of water infiltration. Moreover, studies in the north region were conducted on soils after application of $\mathrm{N}$ fertilizers. In our study, however, precautions were undertaken to avoid soil sampling from fertilized fields.

\section{Nitrate-N Loading in Reservoir}

One of the objectives of this study was to estimate the impact of agricultural, land in the watershed (nonpoint source of nitrate- $\mathrm{N}$ contamination) on water quality in WT reservoir.

TABLE 4

Predicted nitrate- $\mathrm{N}$ concentration $(\mathrm{mg} / \mathrm{L})$ in runoff and leaching water for 12 major soils under different land covers in Wagon Train watershed, Lancaster County, Nebraska

\begin{tabular}{|c|c|c|c|c|c|c|}
\hline \multirow[b]{2}{*}{ Soil (map unit) } & \multicolumn{3}{|c|}{$\mathrm{NO}_{3}-\mathrm{N}$ conc in runoff water } & \multicolumn{3}{|c|}{$\mathrm{NO}_{3}-\mathrm{N}$ conc. in leaching water } \\
\hline & Fallow & $\begin{array}{r}\text { Cropland } \\
-(\mathrm{mg} / \mathrm{L})\end{array}$ & Grassland & Fallow & $\begin{array}{r}\text { Cropland } \\
-(\mathrm{mg} / \mathrm{L})\end{array}$ & Grassland \\
\hline Wymore (WtB) & 2.06 & 2.25 & 1.31 & 11.37 & 11.37 & 5.73 \\
\hline Wymore (WtC2) & 1.32 & 1.44 & 1.34 & 7.27 & 7.27 & 5.87 \\
\hline Wymore (WtD3) & 1.28 & 1.40 & 0.81 & 7.07 & 7.07 & 3.55 \\
\hline Pawnee $(\mathrm{PaC} 2)$ & 1.56 & 1.70 & 0.99 & 8.59 & 8.59 & 4.32 \\
\hline Pawnee (PaD2) & 1.42 & 1.55 & 0.09 & 7.82 & 7.82 & 0.39 \\
\hline Nodaway (No, Ns) & 1.78 & 2.08 & 2.53 & 8.04 & 8.04 & 7.04 \\
\hline Sharpsburg (ShC, ShD, ShD2) & 1.83 & 2.13 & 0.51 & 8.38 & 8.38 & 1.45 \\
\hline Mayberry (MeC2, MeD2, MhC3) & 1.42 & 1.56 & 1.24 & 7.81 & 7.81 & 5.39 \\
\hline Colo $(\mathrm{Co}, \mathrm{Cp})$ & 1.82 & 1.99 & 3.33 & 9.41 & 9.41 & 12.87 \\
\hline Judson (JuC) & 1.96 & 2.29 & 2.83 & 8.94 & 8.94 & 8.00 \\
\hline Burchard (BpF, BrD, BrE) & 1.57 & 1.83 & 1.25 & 7.19 & 7.19 & 3.55 \\
\hline Kennebec $(\mathrm{Ke})$ & 1.63 & 1.90 & 0.19 & 7.41 & 7.41 & 0.54 \\
\hline Land cover weighted average & 1.54 & 1.69 & 1.35 & 8.22 & 8.22 & 5.38 \\
\hline Watershed weighted average & & 1.63 & & & 7.88 & \\
\hline
\end{tabular}




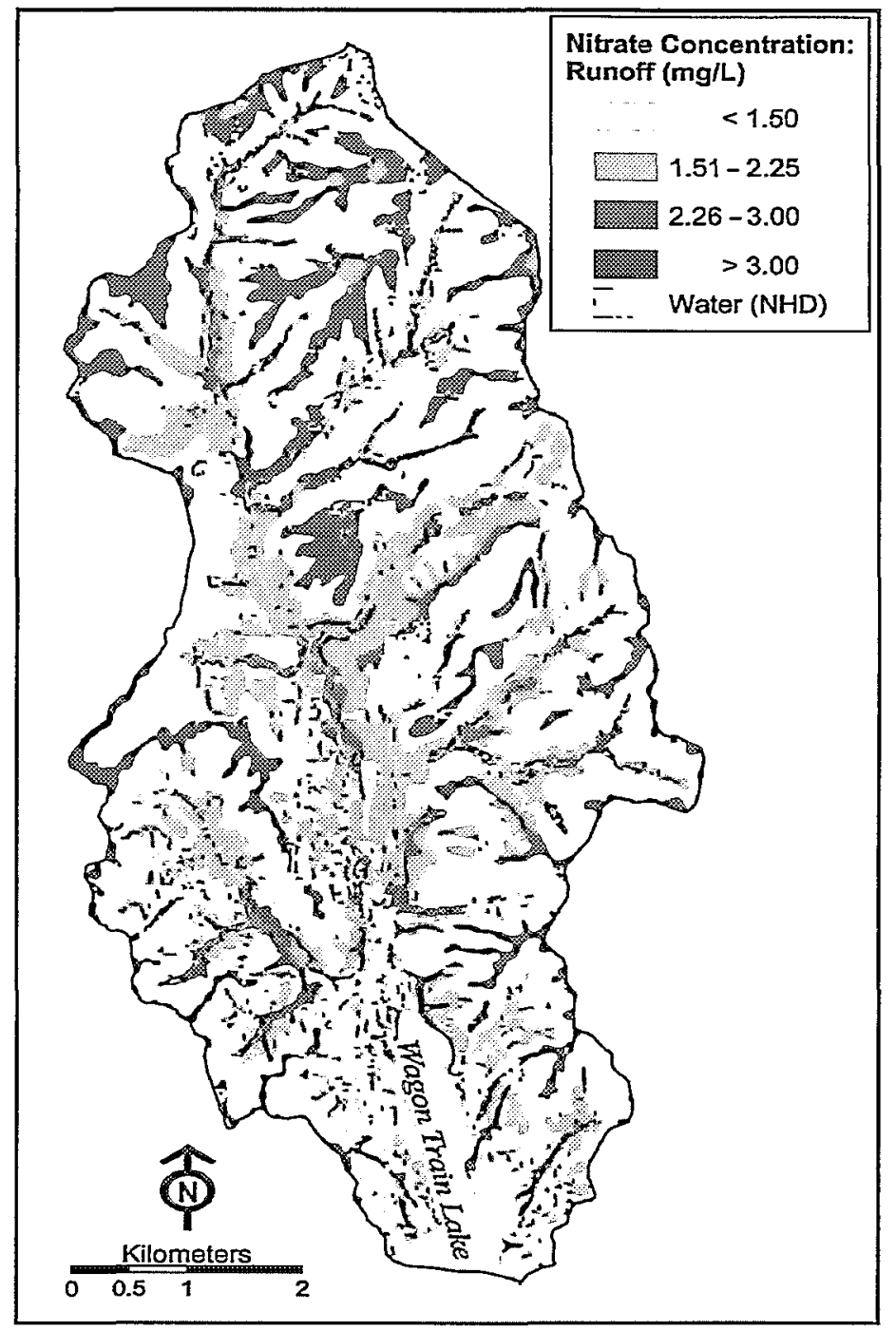

Fig. 3. Nitrate-N concentration in runoff water (mg/L) from soils in Wagon Train watershed, Lancaster County, Nebraska.

The predicted values for both nitrate- $\mathrm{N}$ and water losses by runoff and leaching were used to calculate nitrate-N concentration ( $\mathrm{mg} / \mathrm{L}$ ) $\mathrm{n}$ water generated from soils under fallow, crop, and grass (Table 4). The average nitrate- $\mathrm{N}$ concentration in runoff water was $1.54,1.69$, and $1.35 \mathrm{mg} / \mathrm{L}$ for fallow, cropland, and grassland, respectively. The average nitrate- $\mathrm{N}$ concentration in runoff water from the entire watershed was $1.63 \mathrm{mg} / \mathrm{L}$. On the other hand, the predicted average nitrate- $\mathrm{N}$ concentration in leaching water was higher than that in runoff water. The respective concentrations were $8.22,8.22$, and $5.38 \mathrm{mg} / \mathrm{L}$ for fallow, cropland, and grass- land, whereas the predicted average nitrate$N$ concentration for the entire watershed was $7.88 \mathrm{mg} / \mathrm{L}$.

The predicted nitrate- $\mathrm{N}$ concentration in the runoff water from various soils and land covers in the watershed are illustrated in Fig. 3. The dark area in the map indicates soils producing runoff water with nitrate- $\mathrm{N}$ concentration higher than $2 \mathrm{mg} / \mathrm{L}$. It includes Wymore-WtB, Nodaway, Sharpsburg, and Judson cropped soils as well as Nodaway, Judson, and Colo soils under grass. The total area of these soils (map units) was 865 ha, which accounted for $21 \%$ of the agricultural land in the watershed. 


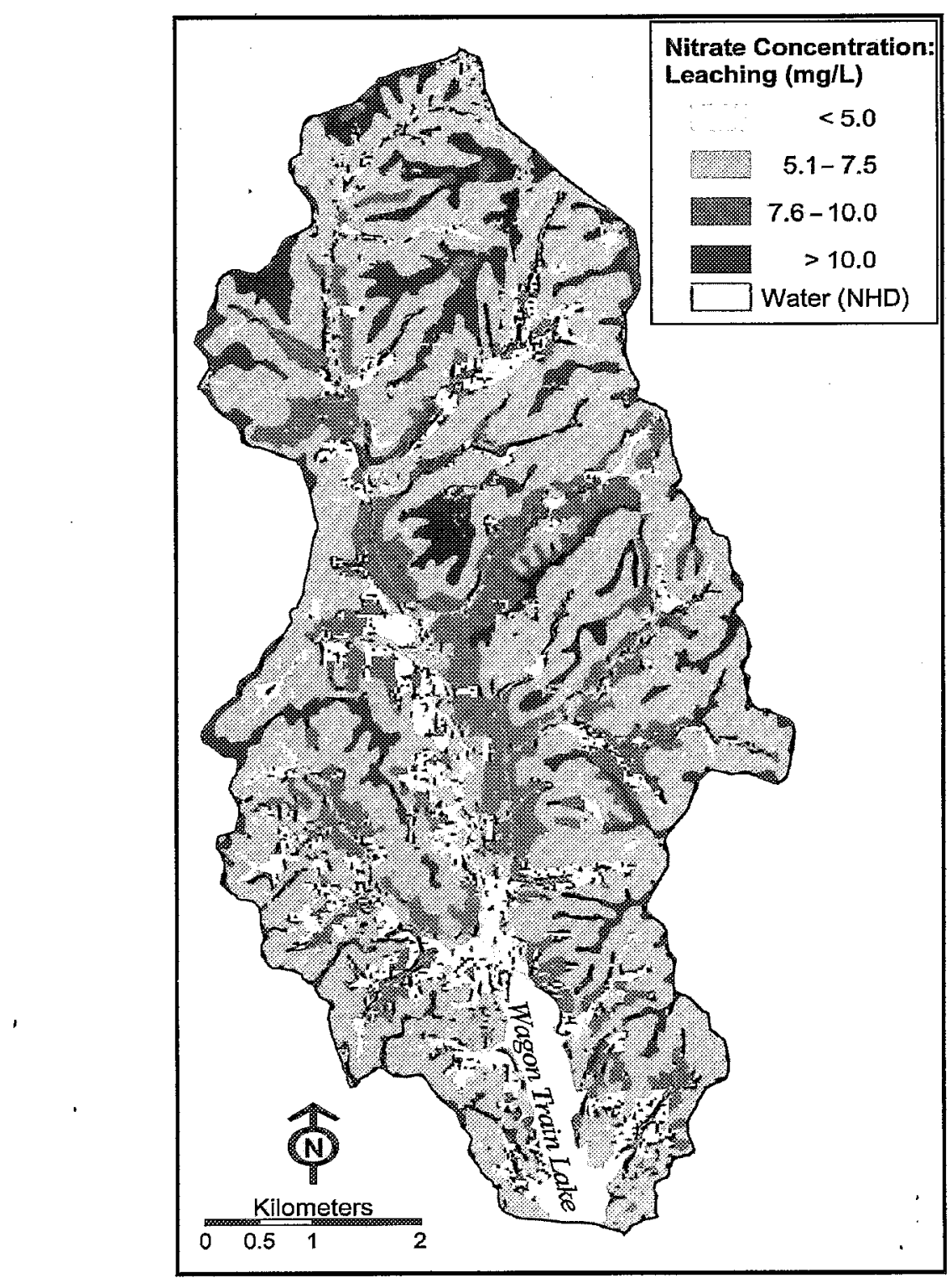

Fig. 4. Nitrate-N concentration in leaching water (mg/L) from soils in Wagon Train watershed, Lancaster County, Nebraska.

The predicted nitrate- $\mathrm{N}$ concentration in leaching water from various soils are shown in Fig. 4. The area in dark color refers to soils under crop and grass that generated leaching water with nitrate- $N$ concentration higher than $7.5 \mathrm{mg} / \mathrm{L}$. However, only cropped Wymore-WtB, and Colo soil under grass generated leaching water with nitrate- $\mathrm{N}$ concentrations exceeding the EPA MCL of $10 \mathrm{mg} / \mathrm{L}$ (USEPA, 1992). The area of the two soils (map units) was $437 \mathrm{ha}$, which is $11 \%$ of the agricultural land in the watershed.
We used the predicted average nitrate- $\mathrm{N}$ concentration in the runoff water, and the average monthly runoff water generated from soils in the watershed to estimate the average monthly nitrate- $\mathrm{N}$ loading to WT reservoir. As mentioned above, the 12 major soils (map units) investigated in this study, incorporated $96 \%$ of the agricultural land in the watershed. Thus, the predicted volume of runoff water was corrected to include the entire watershed area. Then, the corrected runoff along with the average nitrate- $\mathrm{N}$ 


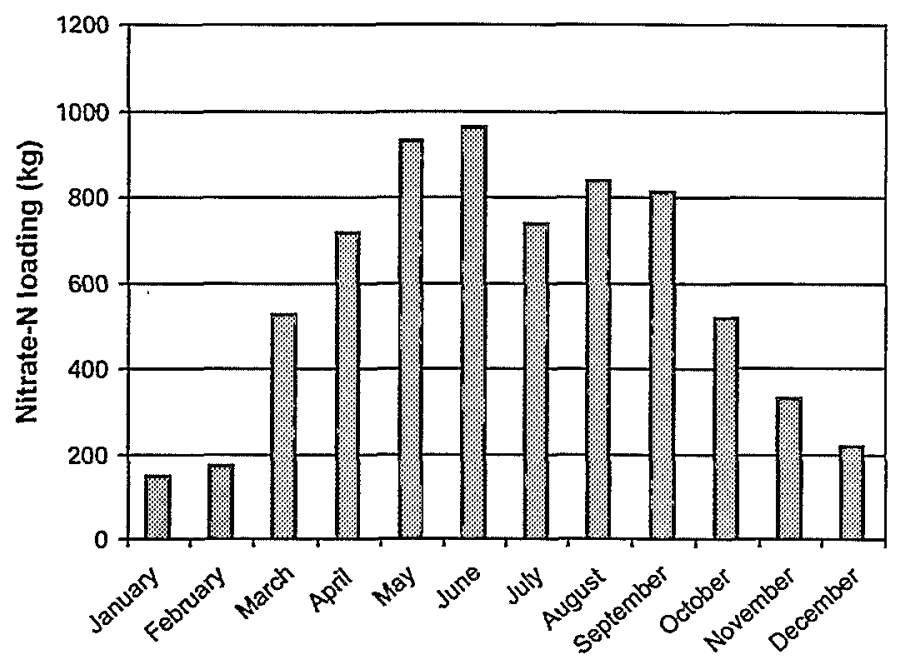

Fig. 5. Predicted average monthly nitrate-N loading by runoff water $(\mathrm{kg})$ into Wagon Train reservoir.

concentration $(1.63 \mathrm{mg} / \mathrm{L})$ were used to calculate the average monthly and annual nitrate- $\mathrm{N}$ loading $(7.04 \mathrm{Mg})$ into WT reservoir.

The predicted average monthly nitrate- $\mathrm{N}$ loading into WT reservoir is shown in Fig. 5. Most of the nitrate- $\mathrm{N}$ charge into the reservoir occurred from April through September where the average monthly loading ranged between 600 and $1000 \mathrm{~kg}$ nitrate- $\mathrm{N}$. The least amount of loading was calculated for winter months, where approximately $200 \mathrm{~kg}$ nitrate- $\mathrm{N}$ per month was charged into the reservoir.

\section{Observed Nitrate-N Concentration}

At the beginning of the rainy season (March), surface water samples were collected at 12 locations in major streams in the watershed (Fig. 1). The nitrate- $N$ concentration in these samples ranged between 0.37 and $1.56 \mathrm{mg} / \mathrm{L}$ with an average of $0.90 \mathrm{mg} / \mathrm{L}(\mathrm{SD}=0.41 \mathrm{mg} / \mathrm{L})$. Meanwhile, the nitrate- $N$ concentration in monthly samples collected for the entire rainy season (March through October) along the main stream before entering the reservoir ranged from 0.36 to $1.45 \mathrm{mg} / \mathrm{L}$ with an average of $0.81 \mathrm{mg} / \mathrm{L}$ $(\mathrm{SD}=0.32 \mathrm{mg} / \mathrm{L}$ ) (Fig. 6). These observed concentrations were generally lower than the predicted average nitrate- $\mathrm{N}$ concentration $(1.63 \mathrm{mg} / \mathrm{L})$ in the runoff water from the entire watershed.

A presence of large populations of algae, weeds, and aquatic plants in streams could assimilate $\mathrm{N}$ and decrease the concentration in water. Further, nitrate loss could be associated

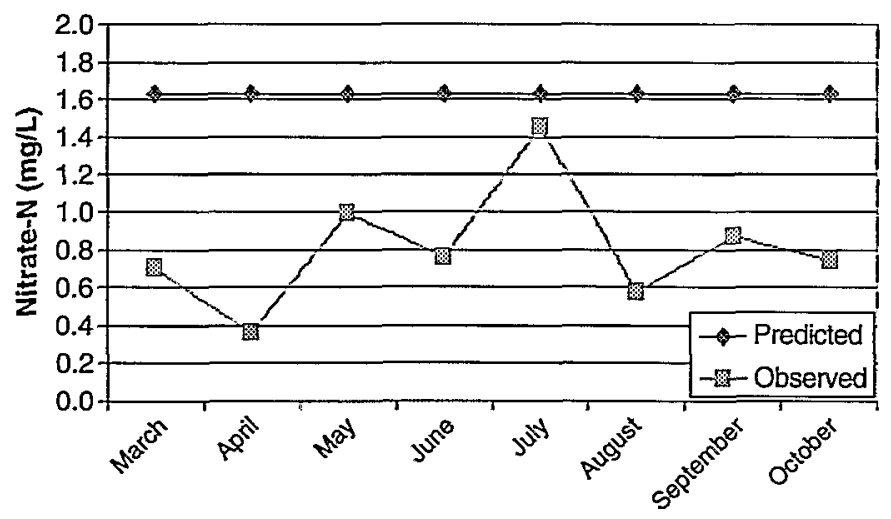

Fig. 6. Predicted and observed nitrate-N concentration (mg/L) in Wagon Train watershed stream water. 
with denitrification. Linn and Doran (1984), and Paul and Clark (1996) reported that under anaerobic conditions, soil nitrate is biologically reduced to $\mathrm{NO}$ and $\mathrm{N}_{2} \mathrm{O}$ gases, where low oxygen concentration and soluble carbon source provides energy for the reaction. Similar processes could take place in freshwater, where heavy growth of algae and aquatic plants consume oxygen and excrete soluble carbon compounds, which enhance nitrate reduction and emission of gaseous nitrogen oxides.

Slightly higher nitrate-N values for WT watershed stream water were reported by other scientists. During the period between May and September 2003,LPSNRD (2004) collected monthly water samples from the main stream just above the reservoir. They found that the, nitrate- $\mathrm{N}$ concentration ranged between 0.34 and 4.78 with an average of $2.09 \mathrm{mg} / \mathrm{L}$.

In conclusion, we must emphasize that the predicted nitrate- $\mathrm{N}$ value was calculated for runoff water generated at field sites and not in stream water. Factors affecting $N$ concentration in runoff water after leaving field sites such as $N$ removal by aquatic weeds and algae as well as denitrification should be taken into consideration. The data suggested that these factors have lowered nitrate- $\mathrm{N}$ concentration by approximately 45 to $50 \%$ (from 163 to 81 to $90 \mathrm{mg} / \mathrm{L}$ ). Therefore, when we consider factors affecting $\mathrm{N}$ concentration in runoff after leaving field sites, the technique could provide a reasonable estimation of $\mathrm{N}$ concentration in stream water.

\section{SUMMARY AND CONCLUSIONS}

Nitrate and other water-soluble chemicals can be transported from agricultural land by surface runoff and subsurface leaching to freshwater bodies. Management activities on cultivated land in high rainfall areas may pose risk to water quality. An exploratory technique was developed that utilizes existing climatic, hydrologic, and soil survey databases to estimate the loss of nitrate- $\mathrm{N}$ by runoff and leaching from agricultural land. The technique applies runoff and percolation models to estimate water loss from agricultural watersheds. The interaction between both runoff and leaching waters and dissolved nitrate- $\mathrm{N}$ in root-zone soil is used to estimate nitrate- $\mathrm{N}$ loss from soil.

For WT watershed, the estimated annual loss of water by runoff was 4.32 million $\mathrm{m}^{3}$ and approximately one million $\mathrm{m}^{3}$ of water for the annual loss by leaching below the root zone. The predicted runoff water was in good agreement with the observed annual inflow for WT reservoir $\left(4.25\right.$ million $\left.\mathrm{m}^{3}\right)$. The estimated annual nitrate- $\mathrm{N}$ loss by runoff from the watershed was $7.0 \mathrm{Mg}$, whereas the loss by leaching was slightly higher, at $7.7 \mathrm{Mg}$. No attempt was made to investigate the fate of water or nitrate lost by leaching below the root zone. It is unlikely, however, that the leaching water and nitrate have any significant impact on the reservoir.

Nitrate- $\mathrm{N}$ concentration in stream water samples collected at the beginning of the rainy season (March) from 12 locations in the watershed ranged between 0.37 and $1.56 \mathrm{mg} / \mathrm{L}$ with an average of $0.90 \mathrm{mg} / \mathrm{L}$. Further, the nitrate-N concentration in monthly samples collected for the rainy season (March through October) along the main stream before entering the reservoir ranged from 0.36 to $1.45 \mathrm{mg} / \mathrm{L}$ with an average of $0.81 \mathrm{mg} / \mathrm{L}$. The observed concentration was generally lower than the predicted nitrate-N concentration of $1.63 \mathrm{mg} / \mathrm{L}$ for the entire watershed. This low nitrate- $\mathrm{N}$ concentration observed in streams could be attributed to the presence of heavy growth of algae, weeds, and aquatic plants as well as denitrification. Assuming that most of runoff water from the watershed flows into the reservoir, the predicted annual nitrate- $\mathrm{N}$ loading was about $7.0 \mathrm{Mg}$ for WT reservoir.

We must emphasize that the predicted nitrate- $\mathrm{N}$ value was calculated for runoff water generated at field sites and not in stream water. When we consider factors affecting $\mathrm{N}$ concentration in runoff after leaving field sites, the technique could provide a.reasonable estimation of $\mathrm{N}$ concentration in stream water. We concluded that the NRCS technique could be used as an exploratory technique to conduct quick evaluations and identify hot spots for large areas of agricultural land. Thus, lengthy and sitespecific studies could be focused on certain areas of high risk.

\section{ACKNOWLEDGMENTS}

The authors acknowledge the input from many individuals at the National Soil Survey Center (NSSC). We are especially grateful to Robert J. Ahrens, NSSC Director, for his support during the course of this study. We also appreciate the invaluable suggestions and constructive criticism from Doug Karlen, Zhenli $\mathrm{He}$, 
and Tom Reedy. The authors also thank members of the Soil Survey Laboratory: Patty Jones, Crystal Schaecher, Chris Lee, Tom Zimmer, and Jan Lang for soil and water analysis.

\section{REFERENCES}

American Society for Testing and Materials (ASTM). 1993. Annual book of ASTM standards. Construction. Section 4. Soil and rock; dimension stone; Geosynthesis. Vol. 04.08. ASTM, Philadelphia, PA.

Bishop, R. 1994. A local agency's approach to solving the difficult problem of nitrate in the groundwater. J. Soil Water Cons. 49:82-84.

Brown, L. E., L. Quandt, S. Scheinost, J. Wilson, D. Witte, and S. Hartung. 1980. Soil Survey of Lancaster County, Nebraska. U.S. Department of Agriculture, Soil Conservation Service. P. 1-174.

Donigian, A.S., Jr., D. C. Beyerlein, H. H. Davis, and N. H. Crawford. 1977. Agricultural runoff management (ARM) model version, II: Refinement and testing. EPA 600/3-77-098.m Environ. Res. Lab., U.S. Environmental Protection Agency, Athens, GA.

Elrashidi, M. A., M. D. Mays, J. L. Harder, D. Schroeder, P. Brakhage, S. D. Peaslee, and C. Schaecher. 2005. Loss of phosphorus by runoff for agricultural watersheds. Soil Sci. 170:5+3-558.

Elrashidi, M. A., M. D. Mays, and P. E. Jones. 2003. A technique to estimate release characteristics and runoff phosphorus for agricultural land. Commun. Soil Sci. Plant Anal. 34:1759-1790.

Elrashidi, M. A., M. D. Mays, S. D. Peaslee, and D. G. Hooper. 2004. A technique to estimate nitratenitrogen loss by runoff and leaching for agricultural land, Lancaster County, Nebraska. Commun. Soil Sci. Plant Anal. 35:2593-2615.

ESRI. 2003. Environmental Systems Research Institute, ArcGIS Version 8.3 [Online]. Available at http://www.esri.com.

Frere, M. R., J. D. Ross, and L. J. Lane. 1980. The nutrient sub-model. Chapter 4. In: W. G. Knisel (ed.). CREAMS a field scale model for chemicals, runoff and erosion from agricultural management systems, USDA-SEA-Conserv. Res. Rep. No. 26. 1:65-86.

Fruh, G. E. 1967. The overall picture of eutrophication. J. Water Pollution Cont. Fed. 39:1+49-1463.

Gast, R. G., W. W. Nelson, and G. W. Randall. 1978. Nitrate accumulation in soils and loss in tile drainage following nitrogen application to continuous com. J. Environ. Qual. 7:258-262.

Gilbert, W. A., D. J. Graczyk, and W. R. Krug. 1987. Average annual runoff in the United States, 1951-1980. Hydrologic investigations. National Atlas HA-710, U.S. Geological Survey, Reston, VA.

Gormly, J. R., and R. F. Spalding. 1979. Sources and concentrations of nitrate-nitrogen in groundwater of the Central Platte Region, Nebraska. Ground Water. 17:291-301.
Hubbard, R. K., R. A. Leonard, and A. W. Johnson. Nitrate transport on a sandy coastal plain soil underlain by plinthite. Trans. ASAE. 34:802-808, 1991.

Linn, D. M. and J. W. Doran. 1984. Effect of waterfilled pore space on carbon dioxide and nitrous oxide production in tilled and nontilled soils. Soil Sci. Soc. Am. J. 48:1267-1272.

Lowrance, R 1992. Nitrogen outputs from a fieldsize agricultural watershed. J. Environ. Qual. 21: 602-607.

LPSNRD. 2004. Lower Platte South Natural Resources District. A community-based watershed management plan for Wagon Train Lake, Lancaster County, Nebraska. Nebraska Department of Environmental Quality, Lincoln, NE.

NASS. 2003. National Agticultural Statistics Service [Online]. Available at http://www.nass.usda.gov/ ne. USDA, NASS, Washington, D.C.

NLCD. 1992. National Land Cover Data for Nebraska. Version 05-07-00 nominal Thematic Mapper. http://landcover.usgs.gov/natllandcover.html.

NWCC. 2003. National Water \& Climate Center. http://www.WCC.NRCS.gov/water/W_CLIM. html.

Olsen, R. J., R. F. Hensler, O. J. Attoe, S. A. Witzel, and L. A. Peterson. 1970. Fertilizer nitrogen and crop rotation in relation to movement of nitrate nitrogen through soil profiles. Soil Sci. Soc. Am. Proc. 34:448-452.

Paul, E. A. and F. E. Clark. 1996. Soil microbiology and biochemistry. 2nd Ed. Academic Press, San Diego, CA.

Rasse, D. P., J. T. Ritchie, W. R. Peterson, T. L. Loudon, and E. C. Martin. 1999. Nitrogen management impacts on yield and nitrate leaching in inbred maize systems. J. Environ. Qual. 28:1365-1371.

Schepers, J. S., M. G. Moravek, E. E. Alberts, and K. D. Frank. 1991. Maize production impacts on groundwater quality. J. Environ. Qual. 20:12-16.

Timmons, D. R., and A. S. Dylla. 1981. Nitrogen leaching as influenced by nitrogen management and supplemental irrigation level. J. Environ. Qual. 10:421-426.

USDA/NRCS. 1996. Soil Survey Laboratory Methods Manual. Soil Survey Investigations Report No. 42, Version No. 3. USDA-NRCS, Washington, D.C.

USDA/NRCS. 1999. Soil Survey Geographic (SSURGO) database for Lancaster County, Nebraska. http://wwww.ftw.nres.usda.gov/ssur_data. html.

USDA/SCS. 1991. National Engineering Field Manual. Chapter 2: Estimating Runoff and Peak Discharges. USDA-NRCS, Washington, D.C. pp. 1-19.

USEPA. 1992. Managing nonpoint source pollution. Final report to congress on section 319 of the Clean Water Act, EPA-506/9-90. Washington, D.C.

USGS. 2001. United States Geological Survey. Water resource data, Nebraska water year 2000. Platte river basin, Lower Platte River Basin, Salt Creek 
at Roca. pp. 180-181. Water-Data Report NE00-1. U.S. Department of the Interior, U.S.G.S., Washington, D.C.

Williams, J. R, and D. E. Kissel. 1991. Water Percolation: an indicator of nitrogen-leaching potential. Chapter 4. In: R. F. Follett, D. R. Keeney, and $R$. M. Cruse (eds.). Managing nitrogen for groundwater quality and farm profitability. Soil Sci. Soc. Am., Madison, WI. pp. 59-83.

Wu, J. J., D. J. Bernardo, H. P. Mapp, S. Geleta, M. L. Teague, K. B. Watkins, G. J. Sabbagh, R. L. Elliott, and J. F. Stone. 1997. An evaluation of nitrogen runoff and leaching potential in the High Plains. J. Soil Water Cons. pp. 52:73-80. 